\title{
MULTI-CRITERIA DECISION MAKING TRENDS IN ECOTOURISM AND SUSTAINABLE TOURISM
}

\author{
Dušan Garabinović ${ }^{1}$, Miloš Papić2 ${ }^{2}$ Marija Kostićc \\ *Corresponding author E-mail: milos.papic@ftn.kg.ac.rs
}

\begin{abstract}
A R T I C LE IN F O
Original Article

Received: 29 December 2020

Accepted: 25 May 2021

doi:10.5937/ekoPolj2102321G

UDC 338.48-53:502/504

$338.482: 303.4$

\section{Keywords: \\ multi-criteria decision making (MCDM), tourism, ecology, sustainability, literature overview}

JEL: C44, L83, Z32

\begin{abstract}
A B S T R A C T
The goal of this paper is to provide a comprehensive overview of application of multi-criteria decision making (MCDM) methods in papers from the field of ecotourism and sustainable tourism. A search has been done of the relevant terms in titles, abstracts and keywords found in papers from 26 prominent journals from the field of tourism belonging in Web of Science (WoS) Clarivate Analytics. It has been established which MCDM methods were used and who are the most common authors of such papers. A keyword frequency analysis was also performed. It is established there are 39 papers in the field of ecotourism and sustainable tourism where MCDM methods were applied whereby all were published after the year 2000, as well as that their number is constantly increasing.
\end{abstract}

(C) 2021 EA. All rights reserved.

\section{Introduction}

Due to an exponential increase in the global focus on sustainable development, a new area of tourism appeared based on its principles. According to Maksin et al. (2009), sustainable tourism first appeared in the early $20^{\text {th }}$ century, and its main characteristic is that it "makes a lasting contribution to the environmental improvement, social wellbeing, economic prosperity and the conservation of natural and man-made resources, cultural values and local community identity" (p. 16). UNEP \& WTO (2005) define sustainable tourism as "tourism that takes full account of its current and future economic, social and environmental impacts, addressing the needs of visitors, the industry, the environment and host communities" (p. 12).

1 Dušan Garabinović, Higher business school of vocational studies "Prof. dr Radomir Bojković", Topličina 12, 37000 Kruševac, Phone: +381 6439295 96, E-mail: dusan. garabinovic.032@gmail.com, ORCID ID: (https://orcid.org/0000-0002-6247-3060)

2 Miloš Papić, Ph.D., Associate Professor, University of Kragujevac, Faculty of Technical Sciences Čačak, Svetog Save 65, Phone: +381 6485253 31, E-mail: milos.papic@ftn. kg.ac.rs, ORCID ID: (https://orcid.org/0000-0001-7628-3439)

3 Marija Kostić, Ph.D., Associate Professor, University of Kragujevac, Faculty of Hotel Management and Tourism in Vrnjačka Banja, Vojvođanska Street 5A, 36210 Vrnjačka Banja, Phone: +381 62283 124, E-mail: marija.kostic@kg.ac.rs, ORCID ID: (https://orcid. org/0000-0001-8105-8033) 
Ecotourism has its own conceptual definition as well. Maksin et al. (2009) define it as an "ecologically responsible journey and a visit to the areas with relatively conserved nature, for enjoying, studying and appreciating the values of nature, landscapes and cultural heritage, promoting and being involved in protecting and enhancing those values, as well as the environment and the local community" (p. 24). Voza \& Fedajev (2020) stand out that for developing countries "ecotourism can be an opportunity for accelerating economic development by exploiting natural resources, without changing their original state" (p. 89). The environmentally sustainable tourism can be distinguished as a strategic determinant not only for the economic, but social development as well (Vuković et al., 2019). On the other hand, Diamantis (1999) argues that "the definition of ecotourism is not really necessary if the discussion focuses on the concepts rather than the issues implied by ecotourism", whereby "the three common concepts within ecotourism are natural-based, educational, and sustainable (which includes economic and social criteria)" (p. 93). As far as the hotel industry is concerned, Kostić et al, (2019) revealed that "the application of green business practices, which is in accordance with the principles of environmental protection, positively affects the satisfaction of the guests" (p. 54).

The number of papers on sustainable tourism increased dramatically in the recent past according to Ruhanen et al. (2015). They conducted a 25-year bibliographic analysis in the four best ranked tourism journals and came to the conclusion that despite the increase in the number of published papers, the subjects and topics remained constant. Also, most papers were case studies, empirical studies and critical reviews. The increase in the number of papers on sustainable tourism was also indicated by Zolfani et al. (2015).

In the sphere of sustainable tourism and ecotourism, there are numerous factors i.e. criteria which are to be taken into consideration upon decision-making. Therefore, the methods of multi-criteria decision making have found application in these fields as well. Multi-criteria decision making (MCDM) has been present in science since the middle of the $20^{\text {th }}$ century but the number of papers published on the application of MCDM to various fields has been increasing since the 90s (Köksalan et al. 2011). An increasing number of academic publications in this field made various authors to deal with its systematization. However, not a single paper referred to the use of MCDM in the field of ecotourism and sustainable tourism.

Thus, based on the aforementioned, the overall goal of this paper was the overview of multi-criteria decision making methods implementation in scientific papers which refer to ecotourism and sustainable tourism, and have been published in the most prominent academic journals in the field of tourism. The main research questions were:

- What is the historical trend of knowledge development in the analyzed scientific fields like?

- In which journals were papers mostly published?

- Which methods of MCDM were mostly implemented?

- Which authors were the ones to deal with these topics most often? 
- What are the most frequently used keywords?

- What are the most significant sub-fields of research (key topics)?

\section{Materials and methods}

In order to find the answers to the main research questions, authors conducted a bibliometric analysis - "the quantitative study of physical published units, or of bibliographic units, or of surrogates of either" (Broadus, 1987).

The importance of bibliometric analyses in the field of tourism is seen based on the review of bibliometric papers to this day in this domain (Koseouglu et al., 2016). The application of bibliometric analyses is present in the field of sustainable tourism (Ruhanen et al., 2015; Garrigos-Simon et al., 2018; Sánchez-Cañizares et al., 2018; Della Corte et al., 2019; Niñerola et al., 2019; Segui-Amortegui et al., 2019; Serrano et al, 2019; Jiménez-García et al., 2020; Lima Santos et al., 2020; Moyle et al., 2020; Milalic et al., 2021; León-Gómez et al., 2021; etc.), as well as in the field of ecotourism (Nordin \& Jamal, 2020; Liu \& Li, 2020; Khanra et al., 2021; etc.).

Firstly, a search has been done for the already defined relevant terms in titles, abstracts and keywords of 26 tourism/hospitality related journals with an impact factor from the Web of Science (WoS) Clarivate Analytics. Advanced search options were used on the websites of the journals' publishers: journals.sagepub.com (6 journals); www. sciencedirect.com (8 journals); www.emerald.com (3 journals); www.tandfonline.com (8 journals); onlinelibrary.wiley.com (1 journal).

The search was not limited to a certain data publishing period, but to the entire history of publishing the papers of the analyzed journals. The search has been done during July 2020, based on words which point to ecology i.e. sustainability, and determinants which refer to MCDM, as well as abbreviations or full forms of the most prominent methods, according to Zavadskas et al. (2014), Mardani et al. (2015), etc.: WPM, WSM, AHP, COPRAS, TOPSIS, VIKOR, ELECTRE, MOORA, MULTIMOORA, DEMATEL, SWARA, ANP, PROMETHEE, WASPAS, SAW, ARAS, DEA, MAUT, MCDM, MADM, MCDA, MODM.

Subsequently, content analysis of the results was conducted by reading the full papers. This way it was confirmed whether the certain paper fulfilled the requirements to be included in the dataset for further analysis. Thus, the following has been unequivocally established: Is the method in question truly implemented in the paper or is it there for some other reason? Does a certain abbreviation truly represent some of the methods or does it refer to some other term? Does the paper essentially focus on ecotourism and sustainable tourism or do the listed terms come up for other reasons?

Data about the publications who found themselves in final selection were coded in a simple flat-file database in Excel. The attributes for which values which were entered for each paper were the following: (1) the journal's title; (2) the paper's title; (3) the author's names; (4) the authors' affiliations (institutions and countries); (5) the year of 
publication; (6) keywords; (7) MCDM method used; (8) area of tourism to which the paper refers (ecotourism or sustainable tourism); (9) key topic to which the method is implemented.

The keywords from the papers selected were processed through the Rapid Miner tool, and based on them a word cloud was made where the most frequently used words and phrases were visually highlighted.

In accordance with the aforementioned, figure 1 briefly depicts the structure of the research, whick consists of five phases.

Figure 1. Structure of the research

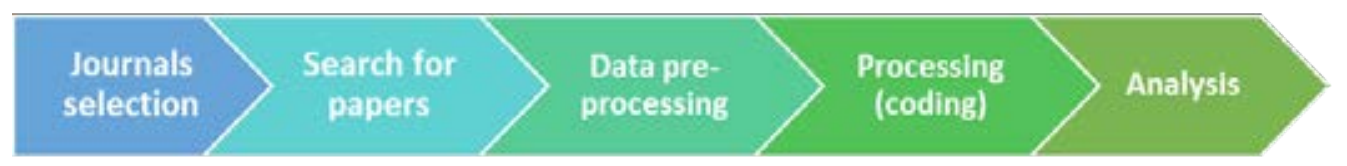

\section{Results and Discussion}

Based on the defined methodology, there were 39 papers in the final selection which were the subject of further analysis.

The following figure shows a yearly dynamics of paper publishing to this day. Each of the papers was published in the $21^{\text {st }}$ century, the oldest one dating from 2002.

Figure 2. Yearly dynamics of paper publishing

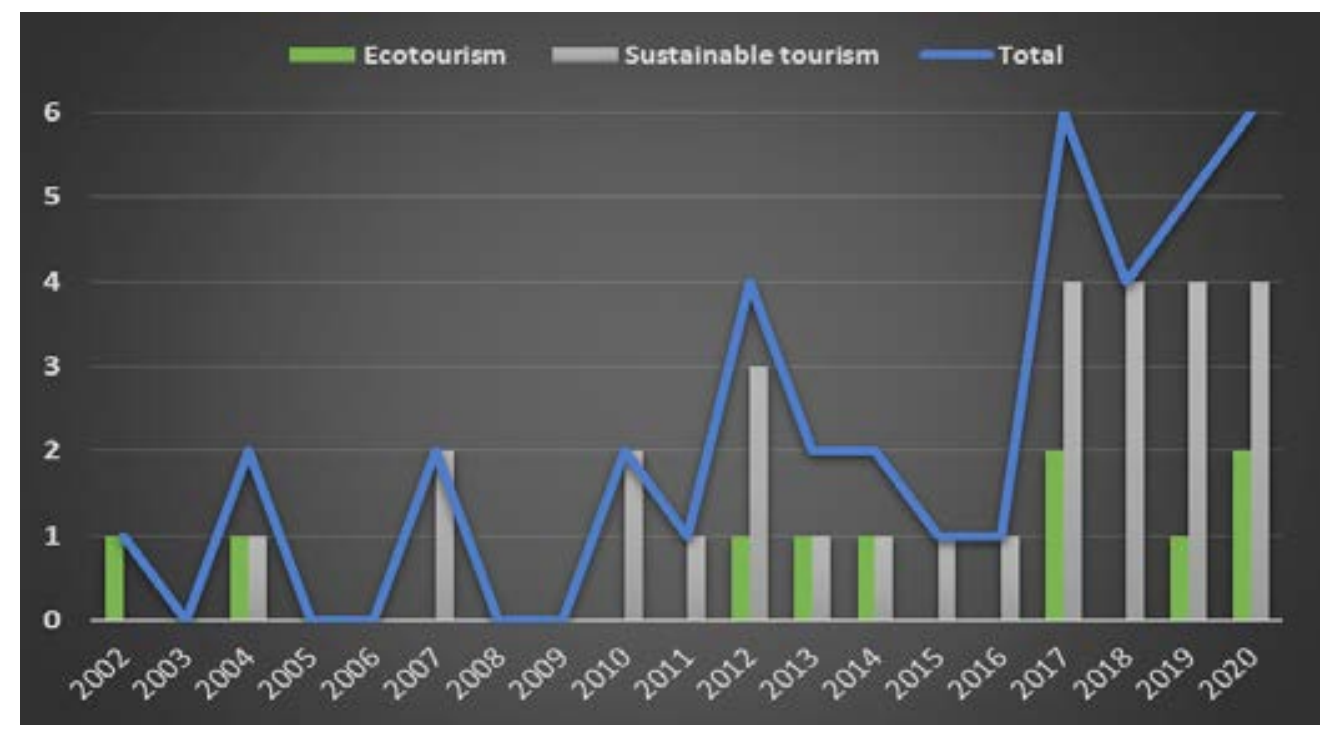

Source: Authors’ research

In the previous decade which makes up half of the time periods since such papers have been published, there were 32 papers published which is $82 \%$ of the total. In the decade before that there were 7 papers published (17.9\%), out of which 2 were from the field of ecotourism, and 5 from the field of sustainable tourism. 
It is expected that the number of papers with the subject theme will continue to increase in the upcoming period, which goes hand in hand with the increase of the number of papers published which deal with MCDM (Zavadskas et al. (2014); Mardani et al. (2015)) and sustainable tourism (Ruhanen et al. (2015); Zolfani et al. (2015)) separately.

For a simpler overview of the results obtained, as well as their discussion, the rest of this section will be shown and explained in four separate chapters which refer to journals, methods, authors and key words and topics.

\section{Part 1: Prominent journals}

The results of the research show that ecotourism and sustainable tourism are the matter of MCDM in about 39 papers which were published in 10 out of 26 analyzed journals (38.46\%). The following table shows journals which had papers published according to the subject matter, as well as the number of such papers in journals and the fields they cover.

Table 1. Number of papers per journal

\begin{tabular}{|c|c|c|c|c|}
\hline \multirow{2}{*}{ Journal } & \multirow{2}{*}{ Ecotourism } & \multirow{2}{*}{$\begin{array}{c}\text { Sustainable } \\
\text { tourism }\end{array}$} & \multicolumn{2}{|c|}{ Total papers } \\
\hline & & & No. & $\%$ \\
\hline Tourism Management & 4 & 5 & 9 & 23.08 \\
\hline Journal of Sustainable Tourism & 2 & 6 & 8 & 20.51 \\
\hline Tourism Economics & 1 & 4 & 5 & 12.82 \\
\hline Asia-Pacific Journal of Tourism Research & 2 & 2 & 4 & 10.26 \\
\hline Current Issues in Tourism & 1 & 2 & 3 & 7.69 \\
\hline International Journal of Tourism Research & 0 & 3 & 3 & 7.69 \\
\hline Tourism Management Perspectives & 0 & 2 & 2 & 5.13 \\
\hline $\begin{array}{c}\text { International Journal of Contemporary Hospitality } \\
\text { Management }\end{array}$ & 0 & 2 & 2 & 5.13 \\
\hline International Journal of Hospitality Management & 0 & 2 & 2 & 5.13 \\
\hline Journal of Hospitality and Tourism Technology & 0 & 1 & 1 & 2.56 \\
\hline TOTAL & 10 & 29 & 39 & 100.00 \\
\hline
\end{tabular}

Source: Authors'research

The greatest number of published papers was in the Tourism Management journal (8 papers, $23.08 \%$ ) which can be related to the impact factor, which is the largest among all analyzed journals. The significant presence of papers published in the Journal of Sustainable Tourism (20.51\%) is logical given the name and subject matter of this journal. Ruhanen et al. (2015) also reported these two journals had the largest number of published papers on sustainable tourism in the period 1987-2012.

The papers which refer to ecotourism (10 papers) can be found in five journals, while papers which refer to sustainable tourism (29 papers) can be found in ten journals. Once again, the most prominent journals are Tourism Management and Journal of Sustainable Tourism. The most probable reason for the disproportion in the number of papers on ecotourism vs. sustainable tourism is that sustainable tourism represents a broader concept. 


\section{Part 2: Prominent methods}

The following table shows a review of established MCDM methods in the analyzed journals. All of the six methods were found only in the Tourism Management journal, while four of them were implemented in the Journal of Sustainable Tourism. Once again, such results are probably a consequence of the high impact factor as well as the journals' topic.

Table 2. Frequency of MCDM methods in journals

\begin{tabular}{|l|c|c|c|c|c|c|c|}
\hline & AHP & ANP & DEMATEL & DEA & VIKOR & ELECTRE & $\begin{array}{c}\text { Total } \\
\text { methods } \\
\text { in journal }\end{array}$ \\
\hline Tourism Management & 2 & 1 & 1 & 3 & 1 & 1 & 6 \\
\hline $\begin{array}{l}\text { Journal of Sustainable } \\
\text { Tourism }\end{array}$ & 2 & 3 & 1 & 1 & 0 & 0 & 4 \\
\hline Tourism Economics & 1 & 0 & 0 & 4 & 0 & 0 & 2 \\
\hline $\begin{array}{l}\text { Asia-Pacific Journal of } \\
\text { Tourism Research }\end{array}$ & 2 & 0 & 0 & 1 & 0 & 0 & 2 \\
\hline Current Issues in Tourism & 0 & 1 & 2 & 0 & 2 & 0 & 3 \\
\hline $\begin{array}{l}\text { International Journal of } \\
\text { Tourism Research }\end{array}$ & 1 & 0 & 0 & 1 & 0 & 0 & 2 \\
\hline $\begin{array}{l}\text { Tourism Management } \\
\text { Perspectives }\end{array}$ & 0 & 0 & 0 & 1 & 0 & 0 & 1 \\
\hline $\begin{array}{l}\text { International Journal of } \\
\text { Contemporary Hospitality } \\
\text { Management }\end{array}$ & 1 & 1 & 1 & 0 & 0 & 0 & 3 \\
\hline $\begin{array}{l}\text { International Journal of } \\
\text { Hospitality Management }\end{array}$ & 0 & 0 & 0 & 2 & 0 & 0 & 1 \\
\hline $\begin{array}{l}\text { Journal of Hospitality and } \\
\text { Tourism Technology }\end{array}$ & 0 & 0 & 1 & 0 & 0 & 0 & 1 \\
\hline Total journals per method & 6 & 4 & 5 & 7 & 2 & 1 & \\
\hline Total papers per method & 9 & 6 & 6 & 13 & 3 & 1 & \\
\hline
\end{tabular}

Source: Authors' research

The method which is most commonly used in papers is DEA (13 papers in 7 journals). This result is in accordance with Emrouznejad's \& Yang's allegations (2018) that DEA is one of the MCDM methods which has experienced exponential growth when it comes to "the number of publications related to its theory and applications". Ashrafi et al. (2013) point out that the "existing literature related to evaluating the efficiency of the hotel industry, generally, uses different types of radial Data Envelopment Analysis (DEA) to compare the relative efficiency of different hotels in a location" (p. 31).

AHP is the next most significant method when it comes to the application in ecotourism and sustainable tourism. Its use is convenient when there are various criteria which can be put into certain categories (Hermann et al., 2007; Agarski et al., 2012), as well as when it is needed to determine the weights of criteria (Papić, 2016) upon which every comparison between two elements of the hierarchy is performed based on the Saaty's Rating scale or so-called "nine-point” scale (Saaty, 2008). 
The following table (Table 3.) shows a review of established MCDM methods in the papers per analyzed topics. The broader conceptual determination of sustainable tourism over ecotourism has prevailed once again in terms of quantitative indicators.

Table 3. Frequency of MCDM methods per topic

\begin{tabular}{|l|c|c|c|c|c|c|c|}
\hline & AHP & ANP & DEMATEL & DEA & VIKOR & ELECTRE & $\begin{array}{c}\text { Total } \\
\text { methods }\end{array}$ \\
\hline Ecotourism & 2 & 2 & 1 & 3 & 0 & 0 & 4 \\
\hline Sustainable tourism & 7 & 4 & 5 & 10 & 3 & 1 & 6 \\
\hline
\end{tabular}

Source: Authors'research

A significant result of this research is the finding that methods such as WPM, WSM, COPRAS, TOPSIS, MOORA, MULTIMOORA, SWARA, PROMETHEE, WASPAS, SAW, ARAS and MAUT haven't been used in papers in the field of ecotourism and sustainable tourism.

\section{Part 3: Prominent authors}

The number of the authors who contributed to the 39 papers analysed is 116 , and that from 20 different countries (Figure 3.).

Figure 3. Authors by countries

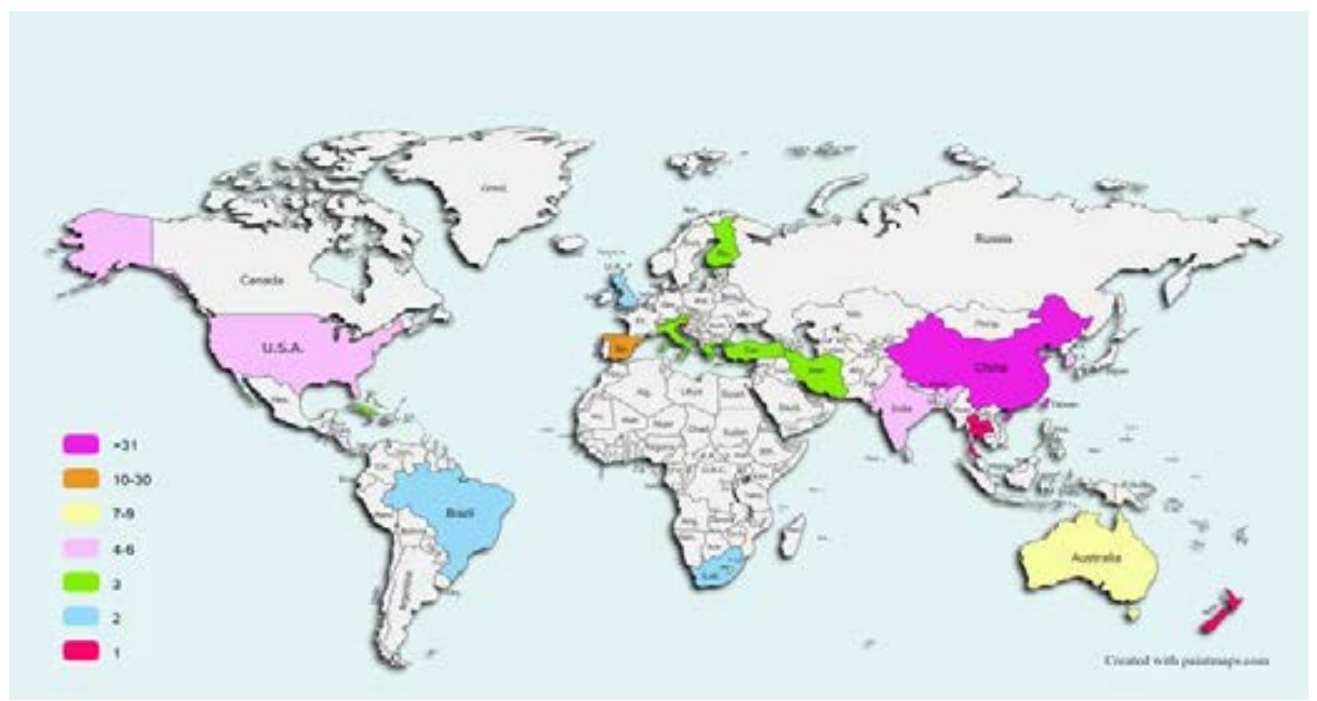

Most of the authors were from China ( $\mathrm{n}=39$ including 18 from Taiwan). The academic interest of Chinese authors in the analyzed research field can potentially be related to the state of the tourism sector in China, which is recording progress. For example, according to the World Bank data, China ranks first in the world for expenditures for travel items. Also, these expenditures were constantly increasing from 1995 to 2018 (World Bank, International tourism, expenditures for travel items (current US\$) China). Moreover, the importance of tourism in China according to the World Bank can be seen by the fact that the number of arrivals has been constantly increasing since 
2014, according to which China ranks third in the world (World Bank, International tourism, number of arrivals - China).

The number of Spanish authors is significant as well $(\mathrm{n}=22)$, upon which 15 contributed to the Navarro Jurado et al. (2012) paper. An average number of authors who contributed to papers while excluding the aforementioned one is 3.07.

The following figure (Figure 4.) shows an overview of authors who have two or more papers with the subject theme. Upon analyzing the authors of subject works, the individuals were taken into consideration irrelevant of being main authors or coauthors i.e. independent of their position.

Figure 4. Most frequent authors ( $\geq 2$ published papers)

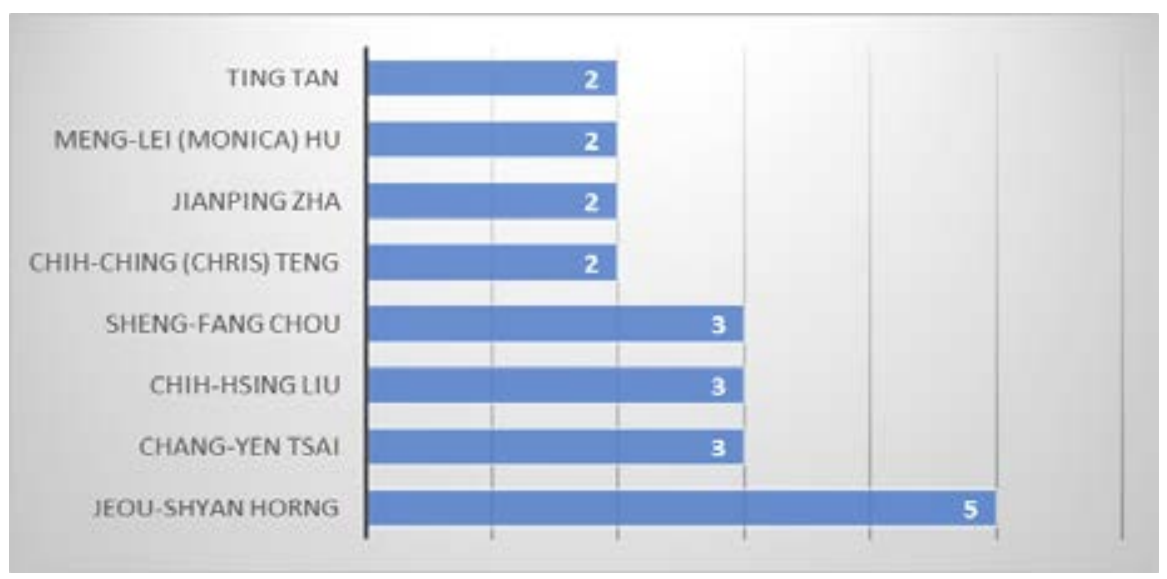

Source: Authors'research

The most prominent author is Jeou-Shyan Horng with five papers published (12.82\% of all papers), four of which she was the main author. Professor Horng has a long and successful research career in the field which can be seen in how many times her papers were cited $(\mathrm{n}=1941)$ and her $h$-index of 23 (Scopus preview - Horng, Jeou Shyan Author details - Scopus, 2021).

What could also be noticed in the previous picture confirms the allegations regarding the engagement of Chinese authors in this research field according to its quantity and quality. According to World Bank data, China ranks first in the world according to the number of Scientific and technical journal articles which was constantly increasing from 2000 to 2018 (the whole period for which data exists) (World Bank, Scientific and technical journal articles - China).

\section{Part 4: Key words and key topics}

The following figure (Figure 5.) shows the most frequent keywords in analysed papers. It can be concluded that the most frequent keyword is Data envelopment analysis which is a full form for the MCDM method DEA. When it comes to the methods, among all the keywords 
the prominent one is Analytic Hierarchy Process - full form for AHP. Such results were expected considering the number of papers where the aforementioned methods were used (13 and 9, respectively). The other prominent keywords were sustainability and multicriteria analyses, which were also expected considering the subject theme of the papers.

Figure 5. Word cloud of the keywords

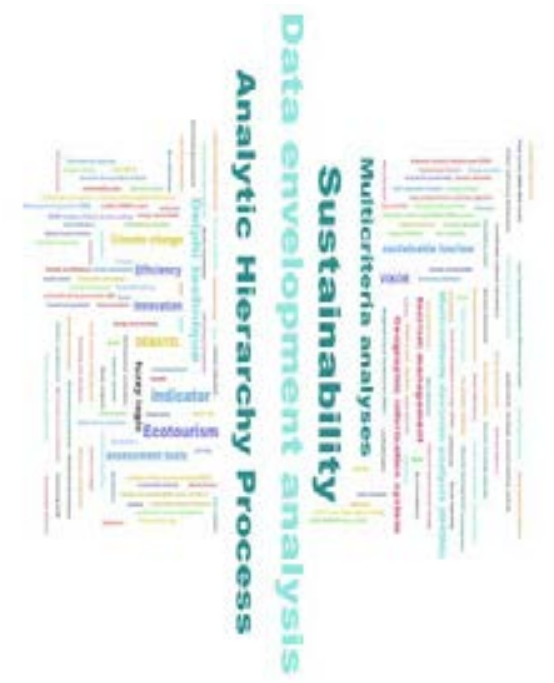

Still, having analysed the 201 keywords which could be found in the 39 papers, the fields of application of MCDM methods could not be fully established. Therefore, the authors had to re-read the papers and single out key topics which were used for MCDM methods in the domain of ecotourism (Table 4.) and sustainable tourism (Table 5.). The authors of the papers with the year of publication, key topics and applied MCDM methods are listed for each paper in both of the tables.

In 8 out of 39 papers there has not been a single MCDM method used which were the subject of the search, but solving certain issues in accordance with the multi criteria approach has been taken into consideration in analysis (multi criteria analysis - MCA), evaluation (multi criteria evaluation - MCE), i.e. decision making (multi criteria decision making - MCDM). The MCDM abbreviation was also used for papers where certain hybrid methods were applied (Hajizadeh et al., 2020). 
Table 4. The review of papers on ecotourism

\begin{tabular}{|c|c|c|}
\hline Author(s) & Topic & $\begin{array}{l}\text { MCDM } \\
\text { method }\end{array}$ \\
\hline $\begin{array}{l}\text { Herath } \\
(2002)\end{array}$ & $\begin{array}{l}\text { The author emphasized the importance of using certain analytical tools in } \\
\text { the ecotourism planning process. }\end{array}$ & MCDM \\
\hline $\begin{array}{l}\text { Zografos \& } \\
\text { Oglethorpe } \\
\quad(2004)\end{array}$ & $\begin{array}{l}\text { The authors emphasized the three-dimensional MCA (adding } \\
\text { sociocultural objectives) and its application in the field of ecotourism, } \\
\text { as well as the importance for the analysis of the preferences of different } \\
\text { stakeholders. Also, the authors demonstrated the possibilities of MCA for } \\
\text { the integration of quantitative and qualitative research approaches. }\end{array}$ & MCA \\
\hline $\begin{array}{l}\text { Horng et al. } \\
\text { (2012) }\end{array}$ & $\begin{array}{l}\text { The authors singled out } 35 \text { energy saving and carbon reduction indicators } \\
\text { based on literature/documents reviews and expert interviews and } \\
\text { determined their relative weights. Their implementation was conducted } \\
\text { through a questionnaire survey which highlighted key elements for } \\
\text { improvement. }\end{array}$ & ANP \\
\hline $\begin{array}{l}\text { Horng et al. } \\
\text { (2013) }\end{array}$ & $\begin{array}{l}\text { The authors developed an innovative physical dining environment design } \\
\text { (IPDE) assessment model for use in restaurants taking into account } \\
\text { the relationship between creativity, eco-friendliness, aesthetics and } \\
\text { performance. }\end{array}$ & $\begin{array}{c}\text { ANP, } \\
\text { DEMATEL }\end{array}$ \\
\hline $\begin{array}{c}\text { Dhami et al. } \\
(2014)\end{array}$ & $\begin{array}{l}\text { The authors used visitors' preferences and physical characteristics of the } \\
\text { environment to map forest ecotourism areas. }\end{array}$ & AHP \\
\hline $\begin{array}{l}\text { Li et al. } \\
(2017)\end{array}$ & $\begin{array}{l}\text { The authors created a framework for evaluating electronic word-of-mouth } \\
\text { (eWOM) and concluded that ecological-biological attractions failed to } \\
\text { make tourists feel very satisfied in various aspects. }\end{array}$ & AHP \\
\hline $\begin{array}{l}\text { Peng et al. } \\
\text { (2017) }\end{array}$ & $\begin{array}{l}\text { The authors analyzed the determinants of eco-efficiency and concluded } \\
\text { that eco-efficiency is continuously increasing, that „eco-efficiency is } \\
\text { more relevant to scale efficiency than to pure technical efficiency“ and } \\
\text { that the development of eco-efficiency has four phases. }\end{array}$ & DEA \\
\hline $\begin{array}{l}\text { Ruan et al. } \\
\text { (2019) }\end{array}$ & $\begin{array}{l}\text { In order to measure ecological security and observe "quality" from } \\
\text { the perspective of "efficiency", the authors created a new model of } \\
\text { evaluation: Driver-Pressure-State-Impact-Response - Data Envelopment } \\
\text { Analysis (DPSIR - DEA). }\end{array}$ & DEA \\
\hline $\begin{array}{l}\text { Zha et al. } \\
(2020)\end{array}$ & $\begin{array}{l}\text { The authors created a model for measuring changes in eco-efficiency and } \\
\text { eco-productivity and broke down the } 6 \text { elements of tourism growth. }\end{array}$ & DEA \\
\hline $\begin{array}{l}\text { Hajizadeh et } \\
\text { al. (2020) }\end{array}$ & $\begin{array}{l}\text { The authors evaluated the possibilities for the development of ecotourism } \\
\text { using Weighted Linear Combinaiton (WLC) and Fuzzy Ordered Weighted } \\
\text { Average (Fuzzy-OWA) methods, concluding that "OWA has a high } \\
\text { potential for modeling complex decision problems because of a new } \\
\text { concept in this method called order weights". }\end{array}$ & MCDM \\
\hline
\end{tabular}

\section{Source: Authors'research}

Based on the data shown it could be concluded that the given MCDM methods were used predominantly for means of planning and development of ecotourism, mainly in places where authors live and work. Table 4 also shows that Horng et al. (2013) have combined two methods - ANP i DEMATEL, which was not visible from data listed in Table 3. 
Table 5. The review of papers on sustainable tourism

\begin{tabular}{|c|c|c|}
\hline Author(s) & Topic & $\begin{array}{l}\text { MCDM } \\
\text { method }\end{array}$ \\
\hline $\begin{array}{l}\text { Kajanus et al. } \\
(2004)\end{array}$ & $\begin{array}{l}\text { The authors used the A'WOT method (a combination of AHP and } \\
\text { SWOT) indicating the importance of local culture to the development } \\
\text { of rural tourism. }\end{array}$ & AHP \\
\hline $\begin{array}{l}\text { Schianetz et } \\
\text { al. }(2007)\end{array}$ & $\begin{array}{l}\text { The authors provide an overview of tools for sustainability assessments } \\
\text { for tourism destinations, considering their characteristics (strengths, } \\
\text { weaknesses, specifics of application to certain areas, examples of use). }\end{array}$ & MCA \\
\hline $\begin{array}{l}\text { Tsaur \& Wang } \\
\quad(2007)\end{array}$ & $\begin{array}{l}\text { The authors proposed a procedure for evaluation of sustainable tourism } \\
\text { development that can be applied to a specific tourist destination ( } 3 \\
\text { elements at the objective level, } 10 \text { at the attribute level and } 28 \text { at the } \\
\text { criterion level). }\end{array}$ & AHP \\
\hline $\begin{array}{l}\text { Lee et al. } \\
\text { (2010) }\end{array}$ & $\begin{array}{l}\text { The authors developed a model for assessing the attractiveness of } \\
\text { the destination in terms of sustainable forest recreation tourism ( } 23 \\
\text { determinants). }\end{array}$ & AHP \\
\hline $\begin{array}{l}\text { Moriarty } \\
(2010)\end{array}$ & $\begin{array}{l}\text { Author compared economic sustainability measures between divisions } \\
\text { of New Zealand's hospitality industry and national tourism exemplars. }\end{array}$ & DEA \\
\hline $\begin{array}{c}\text { Park \& Yoon } \\
(2011)\end{array}$ & $\begin{array}{l}\text { The authors developed community-based rural tourism development } \\
\text { indicators ( } 33 \text { indicators, } 4 \text { dimensions). }\end{array}$ & AHP \\
\hline $\begin{array}{l}\text { Jurado et al. } \\
\quad(2012)\end{array}$ & $\begin{array}{l}\text { The authors created an approach to assess the growth constraints of } \\
\text { coastal tourist destinations. The two main advantages are: 1) "focuses } \\
\text { on an open coastal area with an economy based on mass tourism", 2) } \\
\text { "flexible formula - adaptable to other coastal areas". }\end{array}$ & MCDM \\
\hline $\begin{array}{l}\text { Assaf et al.. } \\
\quad(2012)\end{array}$ & $\begin{array}{l}\text { The authors dealed with the impact of the triple bottom line (TBL) } \\
\text { reporting (social, environmental and economic) on hotel performance, } \\
\text { concluding that extensive reporting on all three dimensions leads to } \\
\text { better performance (environmental reporting in particular). }\end{array}$ & DEA \\
\hline Chan (2012) & $\begin{array}{l}\text { Focus of this paper was on the hotel energy benchmarking framework } \\
\text { based on prevailing conditions in China. }\end{array}$ & DEA \\
\hline $\begin{array}{l}\text { Hu et al. } \\
(2013)\end{array}$ & $\begin{array}{l}\text { The authors created a model for energy conservation and carbon } \\
\text { reduction (ECCR) for restaurants ( } 30 \text { ECCR criteria, } 5 \text { dimensions - } \\
\text { the most important „,buildings“). }\end{array}$ & ANP \\
\hline Hyman (2014) & $\begin{array}{l}\text { The author determined the impact of climate change on beach and non- } \\
\text { beach tourism using " } 43 \text { pre-determined literature-linked indicators" } \\
\text { which include "bio-geophysical, social, technological, economic, } \\
\text { technological and institutional factors". }\end{array}$ & MCDM \\
\hline $\begin{array}{l}\text { Malik \& Bhat } \\
\quad(2015)\end{array}$ & $\begin{array}{l}\text { The authors divided the territory of Kashmir into three parts based on } \\
\text { tourism potential (based on natural and socio-economic characteristics) } \\
\text { and emphasized the importance of tourism carrying capacity (TCC) for } \\
\text { regulating the impact of tourism on the environment. }\end{array}$ & MCE \\
\hline $\begin{array}{l}\text { Michailidou et } \\
\text { al. (2016) }\end{array}$ & $\begin{array}{l}\text { The authors created a "methodological framework to plan, manage } \\
\text { and implement climate change mitigation and adaptation measures } \\
\text { in the tourism context" ("18 mitigation and } 16 \text { adaptation measures } \\
\text { under } 4 \text { criteria i.e. environmental benefit, applicability, cost and social } \\
\text { acceptance"). }\end{array}$ & ELECTRE \\
\hline $\begin{array}{l}\text { Fernández- } \\
\text { Tabales et al. } \\
\quad(2017)\end{array}$ & $\begin{array}{l}\text { The authors created indicator systems of sustainability in tourism } \\
\text { destinations based on the roles of the "public administration, tourism } \\
\text { businesses and the local community" ( } 43 \text { indicators divided into } 5 \text { sub- } \\
\text { systems). }\end{array}$ & AHP \\
\hline
\end{tabular}




\begin{tabular}{|c|c|c|}
\hline Author(s) & Topic & $\begin{array}{l}\text { MCDM } \\
\text { method }\end{array}$ \\
\hline $\begin{array}{l}\text { Pérez et al. } \\
\text { (2017) }\end{array}$ & $\begin{array}{l}\text { The authors were focused on measuring the degree of sustainability of } \\
\text { tourist destinations, taking into account the perception of stakeholders } \\
\text { ( } 3 \text { dimensions - social, economic, patrimonial; } 17 \text { indicators). }\end{array}$ & MCDM \\
\hline $\begin{array}{l}\text { Önder et al. } \\
\text { (2017) }\end{array}$ & $\begin{array}{l}\text { The authors synthesized various frameworks for sustainable tourism } \\
\text { indicators for subnational regions and cities, concluding that it is more } \\
\text { feasible to analyse existing sustainable tourism indicators than to } \\
\text { introduce new measures lacking in direct practical applicability for the } \\
\text { organizations. }\end{array}$ & DEA \\
\hline $\begin{array}{l}\text { Park \& Kim } \\
\quad(2017)\end{array}$ & $\begin{array}{l}\text { The authors used } 153 \text { sustainable practices and their relative } \\
\text { importances/weights for the development of guidelines for a green } \\
\text { convention ( } 7 \text { categories and } 37 \text { subcategories). }\end{array}$ & AHP \\
\hline $\begin{array}{l}\text { Horng, Hsu \& } \\
\text { Tsai (2018) }\end{array}$ & $\begin{array}{l}\text { The authors created an assessment model of corporate social } \\
\text { responsibility (CSR) practice in the field of tourism ( } 5 \text { dimensions i } 15 \\
\text { criteria). }\end{array}$ & $\begin{array}{c}\text { ANP, } \\
\text { DEMATEL }\end{array}$ \\
\hline Chiu (2018) & $\begin{array}{l}\text { The author analyzed the bed and breakfast (B\&B) industry in the } \\
\text { context of managerial efficiency. }\end{array}$ & DEA \\
\hline $\begin{array}{l}\text { van Heerden } \\
\text { \& Saayman } \\
\quad(2018)\end{array}$ & $\begin{array}{l}\text { The authors analyzed the sustainability of national arts festivals } \\
\text { in order to "identify the presence of tendencies to overspend and } \\
\text { budget mismanagement exhibited by visitors at the Innibos National } \\
\text { Arts Festival", creating a framework for the development of "price } \\
\text { discounts or package combos" which needs to be adjusted according to } \\
\text { gender. }\end{array}$ & DEA \\
\hline $\begin{array}{l}\text { Horng et al. } \\
\text { (2018) }\end{array}$ & $\begin{array}{l}\text { For the hospitality industry, the authors are developing a sustainable } \\
\text { service innovation (SSI) framework. }\end{array}$ & $\begin{array}{l}\text { DEMATEL, } \\
\text { ANP }\end{array}$ \\
\hline $\begin{array}{l}\text { Peng \& Tzeng } \\
(2019)\end{array}$ & $\begin{array}{l}\text { The authors explored the feasibility of performance-improving } \\
\text { strategies. }\end{array}$ & $\begin{array}{l}\text { DEMATEL, } \\
\text { VIKOR, ANP }\end{array}$ \\
\hline $\begin{array}{c}\text { Kularatne et } \\
\text { al. (2019) }\end{array}$ & $\begin{array}{l}\text { The authors examined the impact of environmentally sustainable } \\
\text { practices on hotel efficiency. }\end{array}$ & DEA \\
\hline $\begin{array}{c}\text { Andria et al. } \\
\text { (2019) }\end{array}$ & $\begin{array}{l}\text { The authors ranked tourist destinations and evaluated their performance } \\
\text { in terms of sustainability (two-step FAHP-FMCDM method). }\end{array}$ & DEA, AHP \\
\hline $\begin{array}{l}\text { Ozturkoglu et } \\
\text { al. (2019) }\end{array}$ & $\begin{array}{l}\text { The authors identified dimensions for sustainability-oriented hospitality } \\
\text { service innovation (SOHSI) for the food and beverage (F\&B) industry. } \\
\text { The specificity is that not one, but three dimensions were used (social, } \\
\text { environmental and economic; so-called ,triple bottom line - TBL"). }\end{array}$ & DEMATEL \\
\hline Lin (2020) & $\begin{array}{l}\text { The authors evaluated the system of urban and rural tourism based on } \\
\text { four aspects: cultural preservation, environment sustentation, economic } \\
\text { development, and social consciousness. }\end{array}$ & $\begin{array}{l}\text { DEMATEL, } \\
\text { VIKOR }\end{array}$ \\
\hline $\begin{array}{c}\text { Kim \& Chung } \\
(2020)\end{array}$ & $\begin{array}{l}\text { The authors analyzed the visitor return rate of millennials on the } \\
\text { example of national museums. }\end{array}$ & DEA \\
\hline $\begin{array}{l}\text { Zha et al. } \\
(2020)\end{array}$ & $\begin{array}{l}\text { The authors developed an approach to identify the seven elements } \\
\text { of tourism growth ("technological efficiency, technology gap effect, } \\
\text { technological progress, labor input effect, capital input effect, tourism } \\
\text { resource endowment effect, and environmental overload effect"). }\end{array}$ & DEA \\
\hline $\begin{array}{c}\text { Kumar et al. } \\
\text { (2020) }\end{array}$ & $\begin{array}{l}\text { The authors established criteria for evaluating the green performance of } \\
\text { airports using the Best Worst Method (BWM) and VIKOR. It has been } \\
\text { established that "green policies and regulations are the most important } \\
\text { performance criteria for green airports". }\end{array}$ & VIKOR \\
\hline
\end{tabular}


DEMATEL was also combined with other methods in the field of sustainable tourism (primarily VIKOR and ANP) in 4 out of 5 papers where two or three methods were used (Horng, Hsu \& Tsai, 2018; Horng et al., 2018; Andria et al., 2019; Lin, 2020; Peng $\&$ Tzeng, 2019). One could notice that all of the aforementioned papers are of a more recent date, thus, the phenomenon presented could be observed as a future trend.

\section{Conclusions}

Based on the analysis conducted in this paper, important facts were ascertained, ones which refer to the application of MCDM in the field of tourism, taking the component of ecology and sustainability as a whole into consideration. Analyzing the most prominent journals in the field of tourism, it has been established that in 10 journals (out of 26), there are papers which refer to the application of MCDM in ecotourism and sustainable tourism. The total number of analyzed papers is 39, whereas the journal with the most papers published is Tourism Management. All papers were published in $21^{\text {st }}$ century (from the year 2002). Methods used in papers were: DEA (13), AHP (9), ANP (6), DEMATEL (6), VIKOR (3) and ELECTRE (1).

Based on the other specific findings of this research, stated in the results and discussion section, it can be said that the paper represents a strong database but also a knowledge base, and it provides beneficial guidelines for further research in specific academic area.

What this paper lacks is that it focuses solely on journals with an impact factor (IF) in Web of Science (WoS) Clarivate Analytics and not on other means of dissemination scientific results (conference proceedings, monographs, books, dissertations, etc.). This limitation is a good starting point for broadening the quantity of publications where papers of that subject theme can be found. The second direction for further research is broadening the area of the application of the MCDM methods so that it includes tourism in its entirety, not just its specific subfields. Finally, further research could include lesser known MCDM methods.

\section{Aknowledgments}

This study was supported by the Ministry of Education, Science and Technological Development of the Republic of Serbia, and these results are parts of the Grant No. 451-039/2021-14/200132 with University of Kragujevac - Faculty of Technical Sciences Čačak.

\section{Conflict of interests}

The authors declare no conflict of interest.

\section{References}

1. Agarski, B., Budak, I., Kosec, B., \& Hodolic, J. (2012). An approach to multicriteria environmental evaluation with multiple weight assignment. Environmental Modeling \& Assessment, 17, 255-266. https://doi.org/10.1007/s10666-011-9294-y 
2. Andria, J., di Tollo, G., \& Pesenti, R. (2019). Fuzzy multi-criteria decision-making: An entropy-based approach to assess tourism sustainability. Tourism Economics. https://doi.org/10.1177/1354816619885207

3. Ashrafi, A., Seow, H.-V., Lee, L. S., \& Lee, C. G. (2013). The efficiency of the hotel industry in Singapore. Tourism Management, 37, 31-34. https://doi.org/10.1016/j. tourman.2012.12.003

4. Assaf, A. G., Josiassen, A., \& Cvelbar, L. K. (2012). Does triple bottom line reporting improve hotel performance?. International Journal of Hospitality Management, 31(2), 596-600. https://doi.org/10.1016/j.ijhm.2011.08.005

5. Broadus, R. N. (1987). Toward a definition of "bibliometrics". Scientometrics, 12(5-6), 373-379. https://doi.org/10.1007/BF02016680

6. Chan, W. (2012). Energy benchmarking in support of low carbon hotels: Developments, challenges, and approaches in China. International Journal of Hospitality Management, 31(4), 1130-1142. https://doi.org/10.1016/j. ijhm.2012.02.001

7. Chiu, C.-N. (2018). How can managerial efficiency be improved? Evidence from the bed and breakfast industry. Tourism management perspectives, 27, 111-124. https://doi.org/10.1016/j.tmp.2018.06.002

8. Della Corte, V., Del Gaudio, G., Sepe, F., \& Sciarelli, F. (2019). Sustainable tourism in the open innovation realm: A bibliometric analysis. Sustainability, 11(21), 6114. https://doi.org/10.3390/su11216114

9. Dhami, I., Deng, J., Burns, R. C., \& Pierskalla, C. (2014). Identifying and mapping forest-based ecotourism areas in West Virginia-Incorporating visitors' preferences. Tourism Management, 42, 165-176. https://doi.org/10.1016/j.tourman.2013.11.007

10. Diamantis, D. (1999). The concept of ecotourism: Evolution and trends. Current Issues in Tourism, 2(2-3), 93-122. https://doi.org/10.1080/13683509908667847

11. Emrouznejad, A., Yang, G. (2018). A survey and analysis of the first 40 years of scholarly literature in DEA: 1978-2016. Socio-Economic Planning Sciences, 61, 4-8. https://doi.org/10.1016/j.seps.2017.01.008

12. Fernández-Tabales, A., Foronda-Robles, C., Galindo-Pérez-de-Azpillaga, L., \& García-López, A. (2017). Developing a system of territorial governance indicators for tourism destinations. Journal of Sustainable Tourism, 25(9), 1275-1305. https:// doi.org/10.1080/09669582.2016.1260136

13. Garrigos-Simon, F. J., Narangajavana-Kaosiri, Y., \& Lengua-Lengua, I. (2018). Tourism and sustainability: A bibliometric and visualization analysis. Sustainability, 10(6), 1976. https://doi.org/10.3390/su10061976

14. Hajizadeh, F., Poshidehro, M., \& Yousefi, E. (2020). Scenario-based capability evaluation of ecotourism development-an integrated approach based on WLC, and FUZZY-OWA methods. Asia Pacific Journal of Tourism Research, 25(6), 627640. https://doi.org/10.1080/10941665.2020.1752752 
15. Herath, G. (2002). Research methodologies for planning ecotourism and nature conservation. Tourism economics, 8(1), 77-101. https://doi. org $/ 10.5367 / 000000002101298007$

16. Hermann, B. G., Kroeze, C., \& Jawjit, W. (2007). Assessing environmental performance by combining life cycle assessment, multi-criteria analysis and environmental performance indicators. Journal of Cleaner Production, 15(18), 1787-1796. https://doi.org/10.1016/j.jclepro.2006.04.004

17. Horng, J.-S., Chou, S.-F., Liu, C.-H., \& Tsai, C.-Y. (2013). Creativity, aesthetics and eco-friendliness: A physical dining environment design synthetic assessment model of innovative restaurants. Tourism Management, 36, 15-25. https://doi. org/10.1016/j.tourman.2012.11.002

18. Horng, J.-S., Hsu, H., \& Tsai, C.-Y. (2018). An assessment model of corporate social responsibility practice in the tourism industry. Journal of Sustainable Tourism, 26(7), 1085-1104. https://doi.org/10.1080/09669582.2017.1388384

19. Horng, J.-S., Hu, M.-L. (M.), Teng, C.-C. (T.), \& Lin, L. (2012). Energy saving and carbon reduction management indicators for natural attractions: A case study in Taiwan. Journal of Sustainable Tourism, 20(8), 1125-1149. https://doi.org/10.10 80/09669582.2012.663380

20. Horng, J.-S., Liu, C.-H. S., Chou, S.-F., Tsai, C.-Y., \& Hu, D.-C. (2018). Developing a sustainable service innovation framework for the hospitality industry. International Journal of Contemporary Hospitality Management, 30(1), 455-474. https://doi. org/10.1108/IJCHM-12-2015-0727

21. Hu, M.-L., Horng, J.-S., Teng, C.-C., \& Chou, S.-F. (2013). A criteria model of restaurant energy conservation and carbon reduction in Taiwan. Journal of Sustainable Tourism, 21(5), 765-779. https://doi.org/10.1080/09669582.2012.721 787

22. Hyman, T.-A. (2014). Assessing the vulnerability of beach tourism and non-beach tourism to climate change: a case study from Jamaica. Journal of Sustainable Tourism, 22(8), 1197-1215. https://doi.org/10.1080/09669582.2013.855220

23. Jiménez-García, M., Ruiz-Chico, J., Peña-Sánchez, A. R., \& López-Sánchez, J. A. (2020). A bibliometric analysis of sports tourism and sustainability (2002-2019). Sustainability, 12(7), 2840. https://doi.org/10.3390/su12072840

24. Jurado, E. N., Tejada, M. T., García, F. A., González, J. C., Macías, R. C., Peña, J. D., Gutiérrez, F. F., Fernández, G. G., Gallego, Gallego, M. L., García, G. M., Gutiérrez, O. M., Concha, Concha, F. N., de la Rúa, F. R., Sinoga, J. R., F. Solís Becerra, F. S. (2012). Carrying capacity assessment for tourist destinations. Methodology for the creation of synthetic indicators applied in a coastal area. Tourism Management, 33(6), 1337-1346. https://doi.org/10.1016/j.tourman.2011.12.017

25. Kajanus, M., Kangas, J., \& Kurttila, M. (2004). The use of value focused thinking and the A'WOT hybrid method in tourism management. Tourism management, 25(4), 499-506. https://doi.org/10.1016/S0261-5177(03)00120-1 
26. Khanra, S., Dhir, A., Kaur, P., \& Mäntymäki, M. (2021). Bibliometric analysis and literature review of ecotourism: Toward sustainable development. Tourism Management Perspectives, 37, 100777. https://doi.org/10.1016/j.tmp.2020.100777

27. Kim, S., \& Chung, J. (2020). Enhancing visitor return rate of national museums: application of data envelopment analysis to millennials. Asia Pacific Journal of Tourism Research, 25(1), 76-88. https://doi.org/10.1080/10941665.2019.1578812

28. Köksalan, M. M., Wallenius, J., \& Zionts, S. (2011). Multiple criteria decision making: From early history to the 21st century. Singapore: World Scientific. https:// doi.org/10.1142/8042

29. Koseoglu, M. A., Rahimi, R., Okumus, F., \& Liu, J. (2016). Bibliometric studies in tourism. Annals of Tourism Research, 61, 180-198. https://doi.org/10.1016/j. annals.2016.10.006

30. Kostić, M., Ratković, M., \& Forlani, F. (2019). Eco-hotels as an example of environmental responsibility and innovation in savings in the hotel industry. Hotel and Tourism Management, 7(2), 47-56.https://doi.org/10.5937/menhottur1902047K

31. Kularatne, T., Wilson, C., Månsson, J., Hoang, V., \& Lee, B. (2019). Do environmentally sustainable practices make hotels more efficient? A study of major hotels in Sri Lanka. Tourism Management, 71, 213-225. https://doi.org/10.1016/j. tourman.2018.09.009

32. Kumar, A., Aswin, A., \& Gupta, H. (2020). Evaluating green performance of the airports using hybrid BWM and VIKOR methodology. Tourism Management, 76, 103941. https://doi.org/10.1016/j.tourman.2019.06.016

33. Lee, C.-F., Huang, H.-I., \& Yeh, H.-R. (2010). Developing an evaluation model for destination attractiveness: Sustainable forest recreation tourism in Taiwan. Journal of Sustainable Tourism, 18(6), 811-828. https://doi.org/10.1080/09669581003690478

34. León-Gómez, A., Ruiz-Palomo, D., Fernández-Gámez, M.A., \& García-Revilla, M. R. (2021). Sustainable Tourism Development and Economic Growth: Bibliometric Review and Analysis. Sustainability, 13(4), 2270. https://doi.org/10.3390/ su13042270

35. Li, N., Tung, V., \& Law, R. (2017). A fuzzy comprehensive evaluation algorithm for analyzing electronic word-of-mouth. Asia Pacific Journal of Tourism Research, 22(6), 592-603. https://doi.org/10.1080/10941665.2017.1308395

36. Lima Santos, L., Cardoso, L., Araújo-Vila, N., \& Fraiz-Brea, J. A. (2020). Sustainability Perceptions in Tourism and Hospitality: A Mixed-Method Bibliometric Approach. Sustainability, 12(21), 8852. https://doi.org/10.3390/ su12218852

37. Lin, C.-L. (2020). Establishing environment sustentation strategies for urban and rural/town tourism based on a hybrid MCDM approach. Current Issues in Tourism, 23(19), 2360-2395. https://doi.org/10.1080/13683500.2019.1642308 
38. Liu, S., \& Li, W.-Y. (2020). Ecotourism Research Progress: A Bibliometric Analysis During 1990-2016. SAGE Open. https://doi.org/10.1177/2158244020924052

39. Maksin, M., Pucar, M., Korać, M., Milijić, S. (2009). Management of natural and cultural resources in tourism (first edition). Belgrade: Singidunum University. [In Serbian: Maksin, M., Pucar, M., Korać, M., Milijić, S. (2009). Menadžment prirodnih i kulturnih resursa u turizmu (prvo izdanje). Beograd: Univerzitet Singidunum, Fakultet za turistički i hotelijerski menadžment].

40. Malik, M. I., \& Bhat, M. S. (2015). Sustainability of tourism development in Kashmir-Is paradise lost?. Tourism management perspectives, 16, 11-21. https:// doi.org/10.1016/j.tmp.2015.05.006

41. Mardani, A., Jusoh, A., Nor, K.M., Khalifah, Z., Zakwan, N. \& Valipour, A. (2015). Multiple criteria decision-making techniques and their applications - a review of the literature from 2000 to 2014. Economic research - Ekonomska istraživanja, 28(1), 516-571. https://doi.org/10.1080/1331677X.2015.1075139

42. Michailidou, A. V., Vlachokostas, C., \& Moussiopoulos, N. (2016). Interactions between climate change and the tourism sector: Multiple-criteria decision analysis to assess mitigation and adaptation options in tourism areas. Tourism Management, 55, 1-12. https://doi.org/10.1016/j.tourman.2016.01.010

43. Mihalic, T., Mohamadi, S., Abbasi, A., \& Dávid, L. D. (2021). Mapping a Sustainable and Responsible Tourism Paradigm: A Bibliometric and Citation Network Analysis. Sustainability, 13(2), 853. https://doi.org/10.3390/su13020853

44. Moriarty, J. P. (2010). Have structural issues placed New Zealand's hospitality industry beyond price?. Tourism Economics, 16(3), 695-713. https://doi. org/10.5367/000000010792278428

45. Moyle, B., Moyle, C.-1., Ruhanen, L., Weaver, D., \& Hadinejad, A. (2020). Are we really progressing sustainable tourism research? A bibliometric analysis. Journal of Sustainable Tourism, 29(1), 106-122. https://doi.org/10.1080/09669582.2020.1 817048

46. Niñerola, A., Sánchez-Rebull, M.-V., \& Hernández-Lara, A.-B. (2019). Tourism research on sustainability: A bibliometric analysis. Sustainability, 11(5), 1377. https://doi.org/10.3390/su11051377

47. Nordin, M. R., \& A Jamal, S. (2020). A decade of ecotourism research in protected areas: a bibliometric analysis. Social and Management Research Journal, 17(2), 343-370. https://doi.org/10.24191/smrj.v17i2.10561

48. Önder, I., Wöber, K., \& Zekan, B. (2017). Towards a sustainable urban tourism development in Europe: the role of benchmarking and tourism management information systems-A partial model of destination competitiveness. Tourism Economics, 23(2), 243-259. https://doi.org/10.1177/1354816616656247 
49. Ozturkoglu, Y., Sari, F. O., \& Saygili, E. (2019). A new holistic conceptual framework for sustainability oriented hospitality innovation with triple bottom line perspective. Journal of Hospitality and Tourism Technology, ahead-of-print(aheadof-print). https://doi.org/10.1108/JHTT-02-2019-0022

50. Papić, M. (2016). A Combined Multi-Criteria Approach of Soil Quality Analysis. Romanian Journal of Physics, 61(9-10), 1577-1590.

51. Park, D.-B., \& Yoon, Y.-S. (2011). Developing sustainable rural tourism evaluation indicators. International journal of tourism research, 13(5), 401-415. https://doi. org/10.1002/jtr.804

52. Park, H.-Y., \& Kim, D.-K. (2017). In pursuit of an environmentally friendly convention industry. International Journal of Contemporary Hospitality Management, 29(3), 1028-1051. https://doi.org/10.1108/IJCHM-06-2016-0333

53. Peng, H., Zhang, J., Lu, L., Tang, G., Yan, B., Xiao, X., \& Han, Y. (2017). Ecoefficiency and its determinants at a tourism destination: A case study of Huangshan National Park, China. Tourism Management, 60, 201-211. https://doi.org/10.1016/j. tourman.2016.12.005

54. Peng, K.-H., \& Tzeng, G.-H. (2019). Exploring heritage tourism performance improvement for making sustainable development strategies using the hybridmodified MADM model. Current Issues in Tourism, 22(8), 921-947. https://doi.or $\mathrm{g} / 10.1080 / 13683500.2017 .1306030$

55. Pérez, V. E., Santoyo, A. H., Guerrero, F., León, M. A., da Silva, C. L., \& Caballero, R. (2017). Measuring the sustainability of Cuban tourism destinations considering stakeholders' perceptions. International Journal of Tourism Research, 19(3), 318328. https://doi.org/10.1002/jtr.2114

56. Ruan, W., Li, Y., Zhang, S., \& Liu, C.-H. (2019). Evaluation and drive mechanism of tourism ecological security based on the DPSIR-DEA model. Tourism Management, 75, 609-625. https://doi.org/10.1016/j.tourman.2019.06.021

57. Ruhanen, L., Weiler, B., Moyle, B. D., \& McLennan, C.-1. J. (2015). Trends and patterns in sustainable tourism research: A 25-year bibliometric analysis. Journal of Sustainable Tourism, 23(4), 517-535. https://doi.org/10.1080/09669582.2014.978790

58. Saaty, T. L. (2008). Decision making with the analytic hierarchy process. International journal of services sciences, 1(1), 83-98. http://dx.doi.org/10.1504/ IJSSCI.2008.017590

59. Sánchez-Cañizares, S. M., Castillo-Canalejo, A. M., \& Cabeza-Ramírez, L. J. (2018). Sustainable tourism in sensitive areas: Bibliometric characterisation and content analysis of specialised literature. Sustainability, 10(5), 1525. https://doi. org/10.3390/su10051525

60. Schianetz, K., Kavanagh, L., \& Lockington, D. (2007). Concepts and tools for comprehensive sustainability assessments for tourism destinations: A comparative review. Journal of Sustainable Tourism, 15(4), 369-389. https://doi.org/10.2167/jost659.0 
61. Scopus preview - Horng, Jeou Shyan - Author details - Scopus. [online]. Retrieved from https://www.scopus.com/authid/detail.uri?authorId=7103277790 (25 March 2021, 10:44).

62. Segui-Amortegui, L., Clemente-Almendros, J. A., Medina, R., \& Grueso Gala, M. (2019). Sustainability and competitiveness in the tourism industry and tourist destinations: A bibliometric study. Sustainability, 11(22), 6351. https://doi. org/10.3390/su11226351

63. Serrano, L., Sianes, A., \& Ariza-Montes, A. (2019). Using bibliometric methods to shed light on the concept of sustainable tourism. Sustainability, 11(24), 6964. https://doi.org/10.3390/su11246964

64. Tsaur, S.-H., \& Wang, C.-H. (2007). The evaluation of sustainable tourism development by analytic hierarchy process and fuzzy set theory: An empirical study on the Green Island in Taiwan. Asia Pacific Journal of Tourism Research, 12(2), 127-145. https://doi.org/10.1080/10941660701243356

65. UNEP \& WTO (2005) Making Tourism More Sustainable - A Guide for Policy Makers. Paris: UNEP, Division of Technology, Industry and Economics; Capitán Haya, Spain: World Tourism Organization. Retrieved from https:/digitallibrary. un.org/record/561577/files/dtix0592xpa-tourismpolicyen.pdf (22nd November 2020, 14:53).

66. van Heerden, C., \& Saayman, M. (2018). Sustainability of a national arts festival: An application of a data envelopment analysis approach. Tourism Economics, 24(5), 576-592. https://doi.org/10.1177/1354816618762186

67. Voza, D., Fedajev, A., (2020). Strategic approach to the development of ecotourism in Bor District, Serbia. Hotel and Tourism Management, 8(2), 89-100. https://doi. org/10.5937/menhottur2002089V

68. Vuković, D., Hunjet, A., \& Kozina, G. (2019). Environmentally sustainable tourism as a strategic determinant of economic and social development. Turizam, 23(3), 145-156. https://doi.org/10.5937/turizam23-21135

69. World Bank, International tourism, expenditures for travel items (current US\$) - China. [online]. Retrieved from https://data.worldbank.org/indicator/ST.INT.

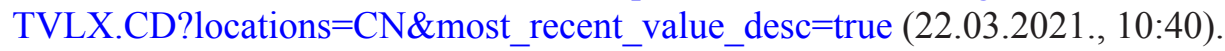

70. World Bank, International tourism, number of arrivals - China. [online]. Retrieved from https://data.worldbank.org/indicator/ST.INT.ARVL?locations=CN\&most recent_value_desc=true (22.03.2021., 10:23).

71. WorldBank,Scientific and technicaljournalarticles-China.[online]. Retrieved from https://data.worldbank.org/indicator/IP.JRN.ARTC.SC?locations=CN\&most recent_value_desc=true $(22.03 .2021 ., 10: 54)$.

72. Zavadskas, E. K., Turskis, Z., \& Kildienè, S. (2014). State of art surveys of overviews on MCDM/MADM methods. Technological and Economic Development of Economy, 20(1), 165-179. https://doi.org/10.3846/20294913.2014.892037 
73. Zha, J., Yuan, W., Dai, J., Tan, T., \& He, L. (2020). Eco-efficiency, eco-productivity and tourism growth in China: a non-convex metafrontier DEA-based decomposition model. Journal of Sustainable Tourism, 28(5), 663-685. https://doi.org/10.1080/09 669582.2019.1699102

74. Zha, J., Zhu, Y., He, D., Tan, T., \& Yang, X. (2020). Sources of tourism growth in Mainland China: An extended data envelopment analysis-based decomposition analysis. International Journal of Tourism Research, 22(1), 54-70. https://doi. org/10.1002/jtr.2318

75. Zografos, C., \& Oglethorpe, D. (2004). Multi-criteria analysis in ecotourism: using goal programming to explore sustainable solutions. Current Issues in Tourism, 7(1), 20-43. https://doi.org/10.1080/13683500408667971

76. Zolfani, S. H., Sedaghat, M., Maknoon, R., \& Zavadskas, E. K. (2015). Sustainable tourism: a comprehensive literature review on frameworks and applications. Economic Research - Ekonomska Istraživanja, 28(1), 1-30. https://doi.org/10.108 0/1331677X.2014.995895 